Article

\title{
Tracking Cobalt, REE and Gold from a Porphyry-Type Deposit by LA-ICP-MS: A Geological Approach towards Metal-Selective Mining in Tailings
}

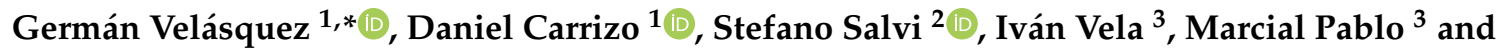 \\ Agustín Pérez $^{3}$ \\ 1 Advanced Mining Technology Center (AMTC), FCFM, Universidad de Chile, Santiago 8370451, Chile; \\ daniel.carrizo@amtc.cl \\ 2 Géosciences Environnement Toulouse (GET), Université de Toulouse, CNRS, GET, IRD, OMP, \\ 14 Av. Edouard Belin, 31400 Toulouse, France; stefano.salvi@get.omp.eu \\ 3 Superintendence of Geology, Los Bronces Underground Project, Anglo American Chile, \\ Santiago 7550103, Chile; ivan.vela@angloamerican.com (I.V.); marcial.pablof@angloamerican.com (M.P.); \\ agustin.perez@angloamerican.com (A.P.) \\ * Correspondence: german.velasquez@amtc.uchlie.cl
}

Received: 22 November 2019; Accepted: 20 January 2020; Published: 28 January 2020

\begin{abstract}
High-resolution mineral characterization performed on mine material from a giant porphyry copper deposit shows that critical and precious metals, such as cobalt, lanthanum, gold, silver, and tellurium, are concentrated in pyrite in the form of visible micro-inclusions, invisible mineral nano-inclusions, and trace metals in the mineral lattice. Visible and invisible inclusions consist of Ag-Au-Te sulfosalt and monazite-(La) particles. Trace metal concentrations grade up to $24,000 \mathrm{~g} / \mathrm{t}$ for cobalt, up to $4000 \mathrm{~g} / \mathrm{t}$ for lanthanum, and up to $4 \mathrm{~g} / \mathrm{t}$ for gold. Pyrite, considered a waste material, is removed from the valuable copper ore material and sent to the tailings. Thus, tailings with high contents of pyrite can represent a prime target to explore for critical metals in the porphyry copper mining operations, transforming it into a new source of supply for critical metals. We propose that high-resolution mineral characterization is the key to evolve from a quasi-single-metal (copper) operation to a multi-metals business by developing metal-selective mining. To address this challenge, we coined the Metal-Zone concept to identify zones enriched in a specific metal within a mineral deposit, instead of zones enriched in an ore mineral.
\end{abstract}

Keywords: ore characterization; porphyry copper deposits; tailings; pyrite; critical metals; REEs; LA-ICP-MS; Metal-Zone; circular economy

\section{Introduction}

Cobalt (Co) has very recently become an essential metal for the development of clean energy technologies [1], mainly due to its use for the production of rechargeable lithium-ion batteries [2,3]. Because of this, Co demand can be expected to exceed known global resources in the near future. Models for green-technology metal requirements have estimated that cobalt needs to exceed at least $150 \%$ of its present-day global production, until 2050 [1]. Additionally, Co supply could be in jeopardy mainly due to (i) mining production being restricted to a single country, i.e., the Congo with up to $70 \%$ of globally available resources, and (ii) metallic Co being concentrated as a by-product in most of the copper and/or nickel deposits, it is not well-characterized by current bulk geochemical analyses. For these reasons, cobalt is classified as a critical metal, i.e., a metal that is crucial for green energy technologies but is at risk of supply-related production issues and/or low geological occurrence $[1,4,5]$. Other critical metals necessary for clean energy technologies include the rare earth elements (REE), 
such as dysprosium (Dy), neodymium (Nd), lanthanum (La), praseodymium (Pr), europium (Eu), and cerium (Ce), as well as silver (Ag), tellurium (Te), and platinum-group metals (PGM) [1,5], all of which have the same supply risk.

Critical metals and gold are known to occur in porphyry copper deposits, with many estimates reporting trace-element concentrations in the order of a few parts per million (ppm) or less (e.g., [6-8]). However, the minerals that host a specific critical metal and the metal distribution through the deposit often are not well-defined in the mining operation protocols. Constrains to this are related to the definition of mineralized zones, Min-Zones in a copper $(\mathrm{Cu})$ mining operation, which is based on copper ore minerals, e.g., $\mathrm{Cu}$-sulfides and $\mathrm{Cu}$-oxides, and also related to the geochemical operational ore characterization, in which analyses are performed taking a "whole mineralized-rock" sample, i.e., a sample constituted of ores as well as barren minerals. This can lead to a number of analytical consequences: (i) The concentration of critical metals can be diluted below the limit of detection in commercial analytical techniques and (ii) whole-rock analyses do not determine which specific mineral hosts each critical metal nor its mode of occurrence in the mine material (Figure 1a). As a consequence, the final destination for critical metals and gold during the metallurgical ore processing remains undetermined in most cases (Figure 1a).

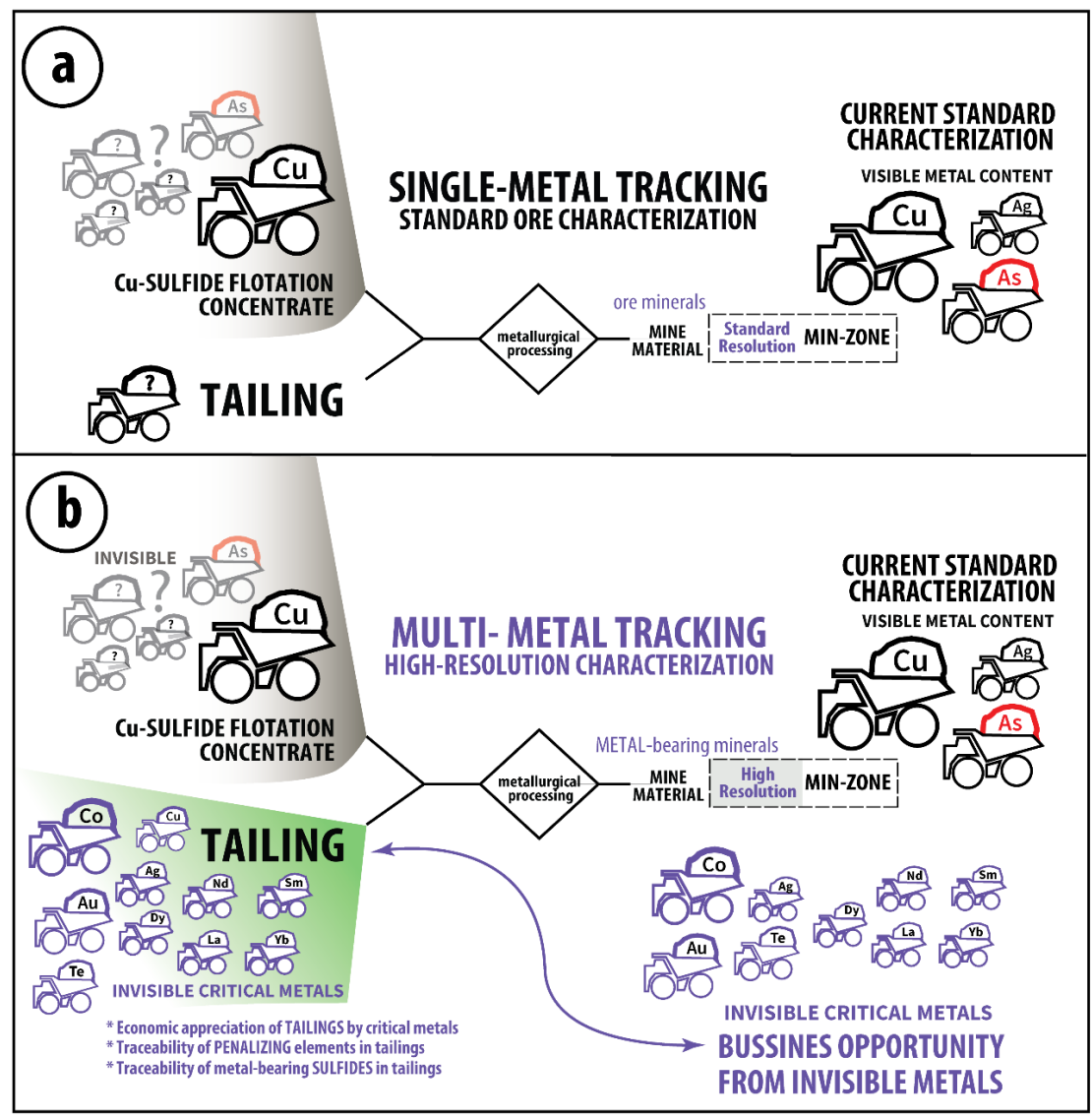

Figure 1. Schematic flow diagram illustrating (a) the current $\mathrm{Cu}$-sulfide ore characterization and metallurgical processing. Here, the main target is copper, and the circuit is fed from a standard characterization of ore material from the Min-Zones, focused on Cu-bearing minerals. The ore is ground, milled, and separated into two portions: a Cu-sulfide flotation concentrate- the final marketing product in our case study - and the rest of the material, which is removed to tailings. (b) High-resolution characterization of all metal-bearing minerals would allow tracking of other economic metals present in trace amounts in the concentrate and tailings, which are ignored in current standard mining, thus providing added business value. The red color of arsenic highlights its deleterious behavior in metallurgical processing. 
The green mining concept promotes exploitation of all metal-bearing minerals and by-products to minimize the amount of waste in a mining operation. According to this concept, one of the main challenges for the modern porphyry copper mining industry is improving its economic and environmental efficiency by evolving from a traditional copper mining $( \pm$ molybdenum \pm gold) (Figure 1a) to a high performing multi-metal business (Figure 1b). To achieve this goal, it is necessary to revise the entire mining value chain, focusing on a mineral characterization that targets the entire metal-bearing paragenesis, rather than only the copper-bearing ore (Figure 1b).

In this paper, we present the results of a pilot study on high-resolution characterization of $\mathrm{Cu}$ sulfide-bearing mine material, focusing on the determination and quantification of economic trace metals (Figure 1b). We applied conventional practices such as petrographic and scanning electron microscope descriptions, combined with more sophisticated techniques such as the "in situ" micro-chemical analysis by laser ablation-inductively coupled plasma-mass spectrometry. The resulting mineralogical and cristallochemical data were used (1) to quantify concentrations for the selected trace metals, i.e., cobalt, REE, and gold; (2) to find the preferential host mineral for each selected critical metal; and (3) to establish preferential metal-enriched zones in the mineral deposit. Finally, we propose a definition for metal-enriched zones, Metal-Zones, a new term coined here for mineralized zones within a deposit, enriched in a specific metal, focusing on a metal-selective mining.

This study was performed on the Los Sulfatos Deposit in the Chilean Central Andes. Managed by Anglo American Chile S.A., this deposit is part of the Los Bronces-Rio Blanco-Los Sulfatos porphyry $\mathrm{Cu}-\mathrm{Mo}$ system, which has one of the highest copper endowments known today (Figure 2) [9-11]. In this study, we will not discuss the concentration of critical metals in ore mineral, such as $\mathrm{Cu}$ sulfides (e.g., chalcopyrite and bornite). Rather, we will focus on determining the concentrations of these metals in minerals that are commonly considered as barren, which are systematically suppressed from the $\mathrm{Cu}$-sulfide flotation concentrate and mostly lost to tailings (Figure 1b).

\section{The Los Sulfatos Deposit (Anglo American-Chile)}

The Los Bronces-Río Blanco-Los Sulfatos porphyry Cu-Mo system (Figure 2) is emplaced in the Miocene to early Pliocene Andean magmatic arc and it is developed in the frontal cordillera of the Chilean Central Andes [9-11]. It is currently exploited in two neighboring open-pit mining operations, namely the Los Bronces Mine, which is managed by the Anglo American Company and the Andina Mine, managed by CODELCO (Corporación Nacional de Cobre, Santiago, Chile). Additional copper resources recently discovered by Anglo American Company [9,10] allowed to index this deposit as one of the largest world class copper districts (>200 Mt of contained copper) [9,10] (Figure 2). These discoveries correspond to the Los Sulfatos Deposit, with more than 3.9 billion tons of resources grading $1.14 \% \mathrm{Cu}$ and to the San Enrique-Monolito Deposit with 0.9 billion tons grading $0.8 \% \mathrm{Cu}$.

The Los Sulfatos deposit (>45 Mt of contained copper) will be developed in the next years as the Los Bronces Underground-Mine Project, in which huge volumes of mineralized material will be extracted throughout the entire life of the mine. This projection represents one of main reason to develop high-resolution characterizations on all metal-bearing minerals (Figure 1b) occurring in the Los Sulfatos Deposit. Determining critical metal content and distribution in the mineralized zones will certainly assist to minimize the amount of waste generated during mining operations. 


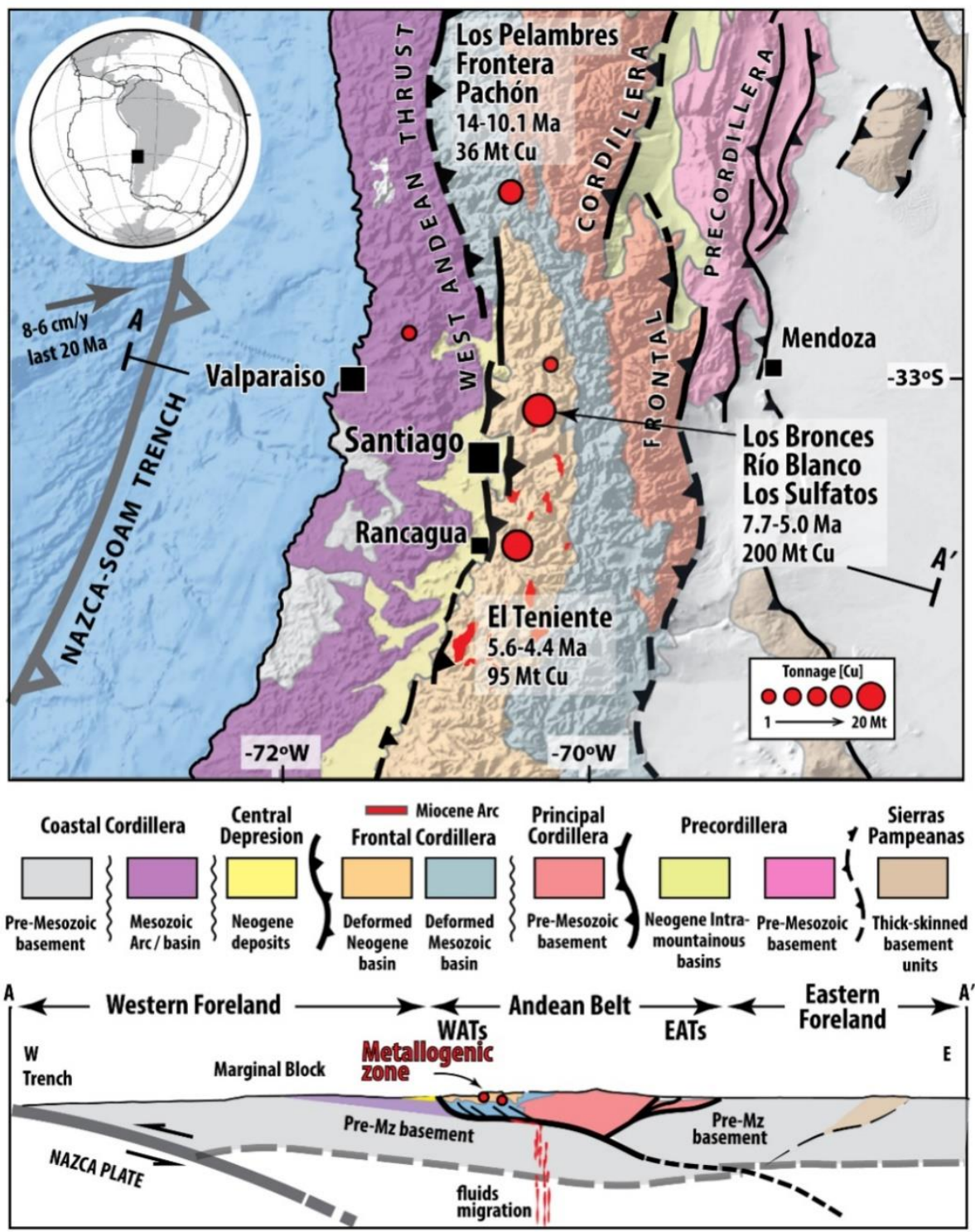

Figure 2. Physiography and first-order tectonic setting of the Central Andes showing the geological framework of the Río Blanco-Los Bronces-Los Sulfatos Cu-Mo porphyry system. Shown also are the location, grades, and general characteristics of the Los Pelambres (36 Mt of contained copper) and El Teniente (95 Mt of contained copper) porphyry copper deposits, which occur in the same metallogenic belt. The cross-section shows the relationships between the porphyry systems and the West Andean Thrust system (modified from Reference [12]).

The simplified metallogenic model for the Los Bronces-Río Blanco-Los Sulfatos porphyry Cu-Mo system [9-11] calls for three ore-forming stages developed in a 2 Ma-long lifespan, continuing mineralizing process: (i) An early hydrothermal stage, during which the porphyry $\mathrm{Cu}-\mathrm{Mo}$ deposit was emplaced; (ii) a superimposed hydrothermal breccia complex, corresponding to the main mineralizing event; and (iii) a last hydrothermal stage, during which polymetallic fault-veins were emplaced. This multistage magmatic-hydrothermal evolution is considered a critical factor that contributed to the enormous copper endowment of the Río Blanco-Los Bronces-Los Sulfatos system [9-11]. This system is emplaced in deformed Neogene volcanoclastic units, and its formation is linked to the evolution of the West Andean Thrust system (WATs), a west-vergence fault and thrust structure that controlled the uplift of the western margin of the Central Andes (e.g., [12,13]) (Figure 2). The main ore paragenesis consists of copper $(\mathrm{Cu}) \pm$ molybdenum (Mo)-bearing sulfides, and for each mineralizing event it comprises of (i) essentially chalcopyrite $\left(\mathrm{CuFeS}_{2}\right)$, bornite $\left(\mathrm{Cu}_{5} \mathrm{FeS}_{4}\right)$, and molybdenite $\left(\mathrm{MoS}_{2}\right)$, accompanied mainly 
by pyrite $\left(\mathrm{FeS}_{2}\right)$ in the early stages; (ii) chalcopyrite and pyrite, accompanied by a minor proportion of chalcocite $\left(\mathrm{Cu}_{2} \mathrm{~S}\right)$ and covellite $(\mathrm{CuS})$ for the main stage case; and (iii) chalcopyrite and minor bornite, accompanied by mainly pyrite and enargite $\left(\mathrm{Cu}_{3} \mathrm{AsS}_{4}\right)$, as well as tennantite $\left((\mathrm{Cu}, \mathrm{Fe})_{12} \mathrm{As}_{4} \mathrm{~S}_{13}\right)$, sphalerite $((\mathrm{Zn}, \mathrm{Fe}) \mathrm{S})$, and galena $(\mathrm{PbS})$ in the late-stage case [9-11].

\section{Analytical Techniques}

Representative drill-core samples from copper mineralized zones of the Los Bronces Deposit were collected, focusing on the areas to be mined during the life of the project. The main object of sampling was to assure that the characterized zones correspond to the material to be extracted during mining operations. Of these, thirty samples were found to be suitable for in-depth investigation of their critical metal content. High-resolution mineralogical studies were carried out at the Géosciences Environnement Toulouse (GET) laboratory in Toulouse, France. Sulfide paragenesis was investigated on 200- $\mu$ m-thick polished sections in reflected and transmitted light, using a polarizing microscope (Nikon Eclipse LV100POL, Nikon instruments Europe, Amsterdam, The Netherlands) equipped with $2 \times, 5 \times, 10 \times, 20 \times$, and $50 \times$ objectives. Based on petrographic descriptions, about 100 sulfide crystals were selected for detailed observation under a scanning electron microscopy (SEM) (JEOL6360LV, JEOL Ltd., Tokyo, Japan) coupled to an energy dispersive X-ray spectrometer (SDD Bruker $129 \mathrm{eV}$, Bruker Corporation, Billerica, MA, USA). The SEM is equipped to acquire images in backscattered electron (BSE) mode with acceleration voltage of $20 \mathrm{kV}$.

Major element (Fe, $\mathrm{S}$, and As) chemical concentrations were determined by electron microprobe (EMPA) using a microprobe (CAMECA SX5, Cameca, Gennevilliers, France), with an acceleration voltage of $25 \mathrm{kV}$ and beam current of $20 \mathrm{nA}$. Trace element concentrations were determined "in situ" on selected metal-bearing sulfides by laser ablation-inductively coupled plasma-mass spectrometry (LA-ICP-MS) analysis using a Ti: sapphire femtosecond (fs) laser, operating at $800 \mathrm{~nm}$ and providing 55 -fs pulses. In the used system, the ablated material is carried in a flow of helium gas $\left(0.46 \mathrm{~L} \mathrm{~min}^{-1}\right)$, which is mixed with argon $\left(1.11 \mathrm{~L} \mathrm{~min}^{-1}\right)$ in a transporting tube connected to a quadrupole ICP-MS. The femtosecond laser Gaussian beam was focused using a $\times 1.75$ microscope objective yielding an energy of $1 \mathrm{~mJ}$ pulse $^{-1}$ on the surface to produce ablation pits of ca. $50 \mu \mathrm{m}$. Raw data were processed online using the GLITTER software package (4.0, ARC National Key Centre for Geochemical Evolution and Metallogeny of Continents, Macquarie University, Sydney, Australia) (e.g., [14]), using pyrrhotite-Po-726 [15], an in-house natural chalcopyrite, Cpy-RM [16], and NIST SRM 610 [17] as external calibrators, in bracketing mode standard-sample-standard and taking ${ }^{57} \mathrm{Fe}$ as the internal calibrator [16]. During analysis, the following isotopes were monitored: ${ }^{33} \mathrm{~S},{ }^{34} \mathrm{~S},{ }^{56} \mathrm{Fe},{ }^{57} \mathrm{Fe},{ }^{59} \mathrm{Co}$, ${ }^{60} \mathrm{Ni},{ }^{63} \mathrm{Cu},{ }^{75} \mathrm{As},{ }^{107} \mathrm{Ag},{ }^{125} \mathrm{Te},{ }^{139} \mathrm{La},{ }^{197} \mathrm{Au},{ }^{208} \mathrm{~Pb}$, and ${ }^{209} \mathrm{Bi}$. Tuning routine is optimized to reduce production of molecular oxide species (typically ${ }^{232} \mathrm{Th}^{16} \mathrm{O} /{ }^{232} \mathrm{Th}<1 \%$ ) and of doubly charged ion species (typically ${ }^{140} \mathrm{Ce}++{ }^{140} \mathrm{Ce}+<2 \%$ ) [16,18], with an analytical precision at a GET of $<15 \%$ RSD [16,18]. Analyses performed by LA-ICP-MS on inclusions of few microns in size (or smaller) are only qualitative, with the purpose of obtaining identification; the data were not tabulated. Detection limits were calculated as three times the background standard deviation value $[16,18]$.

\section{High-Resolution Characterization of Mineralized Zones}

The definition of the mineralized zones in an ore deposit, Min-Zones, is the main focus for the mine geologist and in the case of porphyry copper deposits it is centered on copper-enriched zones. Outlining a Min-Zone consists of a combination of core logging, ore and alteration minerals identification, and lithogeochemical analyses [19]. The resulting data allow the geologist to delineate the copper Min-Zones on a geological 3-D model. When metallic $\mathrm{Cu}$ is the target, attention is paid to $\mathrm{Cu}$-ore, such as $\mathrm{Cu}$-sulfides and $\mathrm{Cu}$-oxides. If, besides copper, critical and precious metals represent the target, it is necessary to consider minerals other than $\mathrm{Cu}$ ore in the paragenesis.

Pyrite is a ubiquitous mineral in practically all porphyry copper on Earth, and it is systematically found in the Min-Zone ore paragenesis and alteration zones [20-22]. From a metallurgical standpoint, 
pyrite is considered having no economic significance [23] and its characterization is only included in the mining planning to control it as deleterious material. However, from a metallogenetic approach, it is well-known that pyrite is very effective in scavenging and concentrating precious metals in hydrothermal systems [20-22,24]. Particularly, in the case of porphyry systems, arsenic-rich pyrite is considered as the main gold-fixing phase $[20,25]$ due to the geochemical decoupling of arsenic from copper $(\mathrm{Cu})$ in the mineralized fluids [25]. Selective partitioning of $\mathrm{Cu}$ from As is the result of a fluid-phase separation process (or boiling), during which a single-phase ore fluid is separated into a low-density $\mathrm{Cu}$-rich vapor and a denser As-rich brine [20,25]. This decoupling triggers preferential $\mathrm{Cu}$-bearing sulfides precipitation in the deeper parts of the porphyry system, while As-bearing sulfides precipitate in shallower parts. In this system, early-formed pyrite, which crystallizes contemporaneously with $\mathrm{Cu}$-sulfides, can concentrate magmatic-related metals, such as cobalt, nickel, and platinum-group metals, while late-formed pyrite is characterized by high arsenic and gold contents [20-22,24-26]. These precious metals hosted in pyrite are not determined in the Min-Zones characterization for most porphyry copper mining operations and go to waste.

This scenario offers an opportunity to explore the economic potential of critical metal contents associated with a porphyry deposit. To evaluate this possibility, we have developed a high-resolution characterization of the main minerals considered as waste, taking as study samples mine material from the four copper Min-Zones defined at Los Sulfatos Deposits, i.e., high-chalcopyrite, low-chalcopyrite, high-bornite, and low-bornite Min-Zones, all of which are developed on hydrothermal breccia [9]. The two following sections describe the mineralogical and cristallochemical characteristics of pyrite in these zones, while a third section deals with the characterization of minerals hosting the precious metals. These features will be used to define the corresponding ore mineral hosting each of the metals of interest in our case study: cobalt, gold, and the rare earth elements.

\subsection{Metal-Bearing Pyrite: Types and Generations}

All pyrite crystals from the Min-Zones investigated in the Los Sulfatos Deposit appear similar at first sight, under reflected light observation (Figure 3). However, after detailed petrographic, microstructural, and textural observations, at least three pyrite types could be recognized (Figures 3 and 4). The first type of pyrite (PY1) is characterized by anhedral to subhedral crystals and contains only few mineral inclusions. PY1 is found systematically intergrown with chalcopyrite (Figure 3a) and occurs within the hydrothermal breccia matrix (Figure 3b). The second pyrite type (PY2) forms euhedral crystals almost free of mineral inclusions (Figure 3c) and, accompanied by chalcopyrite, occurs in mineralized veinlets (Figure 3d). The third pyrite type (PY3, Figure 3e) is characterized by an anhedral core rich in mineral inclusions (Py-core) and a euhedral rim, which is almost inclusions free (Py-rim). PY3 occurs in late-stage veinlets crosscutting the breccia facies (Figure 3f). These late-stage veinlets are considered as "barren" with respect to the copper mineralization.

More than 50 crystals of the three pyrite types were examined under the SEM, and textural and cristallochemical differences between them were recognized (Figure 4). The main discovery was a complex zoning observed in the core of PY3 crystals, consisting of rhythmic alternations of arsenic-rich bands and arsenic-poor zones (Figure 4c,f). Zoning was not observed in PY1 (Figure 4a,d) nor PY2 (Figure 4b,e). Metallic micro-inclusions were found in all pyrite types. In PY1 we identified grains of wolframite (Fe,Mn) $\mathrm{WO}_{4}$ (Figure $4 \mathrm{~d}$ ); in PY2 we found micro-inclusions of a mineral composed of $\mathrm{Au}, \mathrm{Ag}$, and Te, forming rounded grains ( $<5 \mu \mathrm{m}$, Figure 4e); while in PY3, micro-inclusions consisted mainly of visible particles of enargite $\left(\mathrm{Cu}_{3} \mathrm{AsS}_{4}\right)$ (Figure $\left.4 \mathrm{f}\right)$. Visible gold grains were not observed in PY3. The presence of visible metal-bearing particles as micro-inclusions in pyrite suggests that these metals could also be present in an "invisible" form (e.g., $[27,28]$ ); therefore, we verified the content of selected critical metals by analyzing different pyrite types by EMPA (below) as well as by LA-ICP-MS (see the next section). 


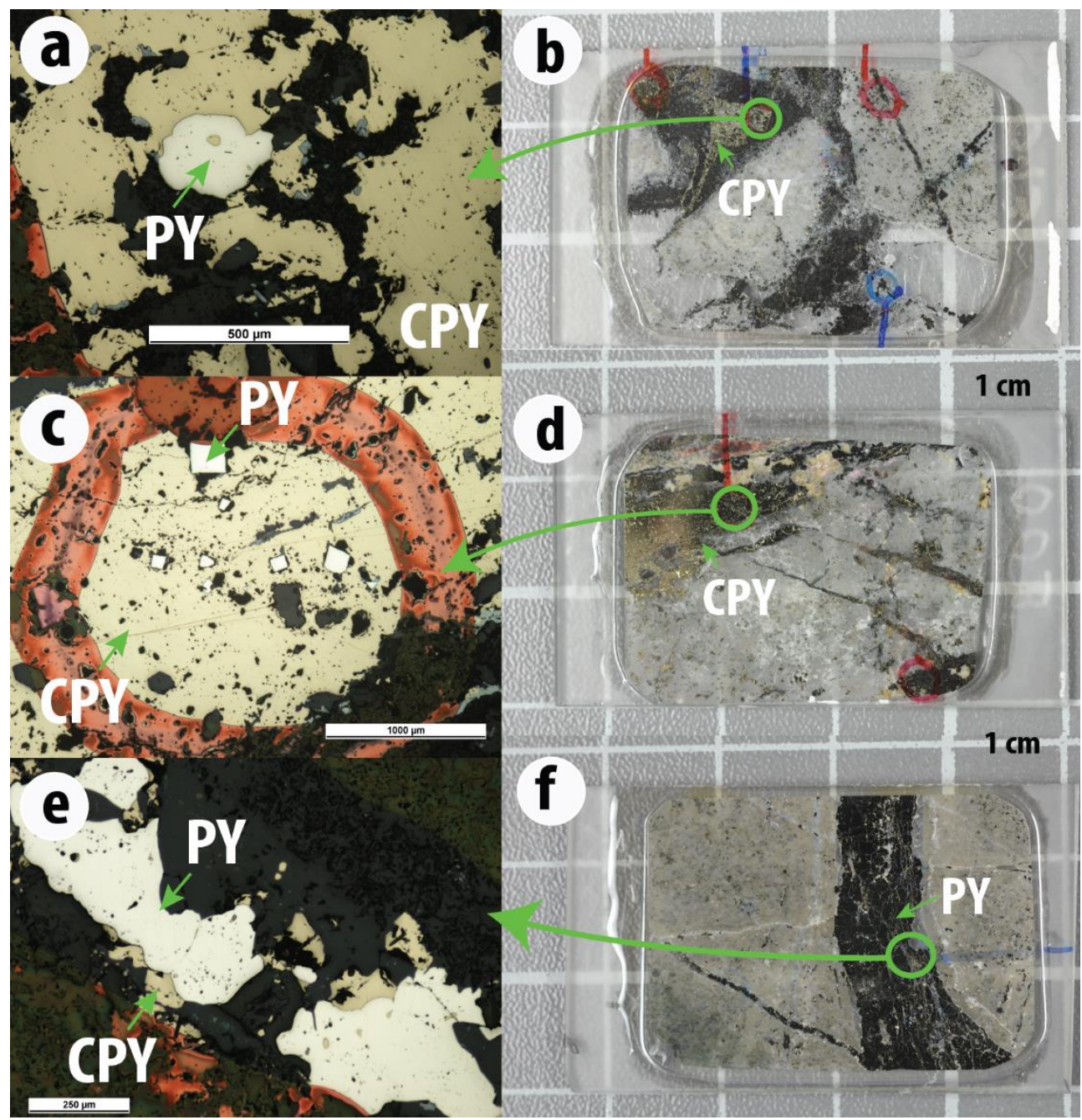

Figure 3. (a,c,e) Photomicrographs under reflected light showing the different types of pyrite recognized in the Los Sulfatos deposit; PY = pyrite; CPY = chalcopyrite. $(\mathbf{b}, \mathbf{d}, \mathbf{f})$ Photographs of 200 - $\mu$ m-thick polished sections showing (in b) breccia with sulfides in the matrix (chalcopyrite and pyrite; PY1); (in d) breccia and mineralized veinlets containing chalcopyrite and euhedral pyrite (PY2), and (in f) late-stage "barren"-veinlets filled with pyrite (PY3), and less abundant late chalcopyrite. Green circles locate the left hand-side images on the thin sections. White lines in the background have $1 \mathrm{~cm}$ interspacing.

Results of the EMPA investigation of PY3 (Figure 5a,b) are reported in Table 1. The average major elements composition of pyrite is $\mathrm{S}=52.6 \pm 0.7 \mathrm{wt} \%$ and $\mathrm{Fe}=46.3 \pm 0.2 \mathrm{wt} \%$. Arsenic concentrations range up to $2.6 \mathrm{wt} \%$ in the As-rich bands, while in the As-poor zones concentrations are below the detection limit of the microprobe ( $\mathrm{LoD}=0.1 \mathrm{wt} \%$; Table 1). Although gold and silver were not detected (Table 1), it is likely that these metals occur in some "invisible" form, i.e., nano-particles and/or in the mineral's lattice [20-22,24-28]. This possibility is supported by the good linear negative correlation between $S$ and As concentrations in PY3 (Figure 5c; $R^{2}=-0.95 ; n=25$ ), suggesting that As substitutes for $\mathrm{S}$ as $\mathrm{Fe}\left(\mathrm{As}_{\mathrm{x}} \mathrm{S}_{1-\mathrm{x}}\right)_{2}$ [27]. This corresponds to arsenian pyrite of the $\mathrm{As}^{1-}$ type, which is a pyrite type systematically associated to gold-enriched zones in orogenic gold [27] as well as porphyry copper deposits [20-22,26]. Noteworthy, for the latter, it has been shown that gold mineralization is generally associated with arsenian pyrites rather than copper-bearing sulfides (e.g., chalcopyrite and bornite) $[26,29]$. 


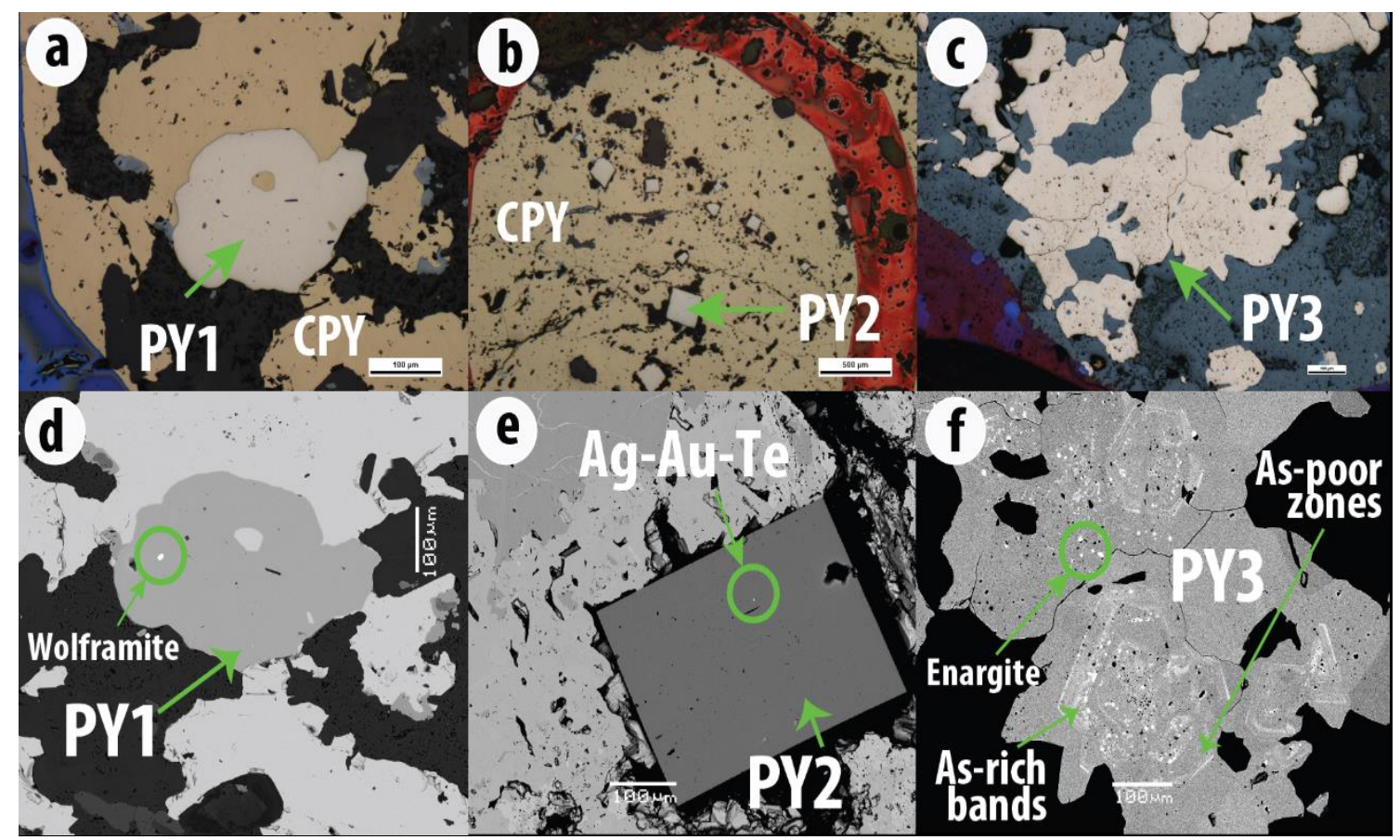

Figure 4. (a,d; b,e; c,f) Photomicrographs (reflected light) and SEM backscattered electron image pairs showing, respectively, occurrences and textural features of PY1, PY2, and PY3 crystals. PY = pyrite; $\mathrm{CPY}=$ chalcopyrite.
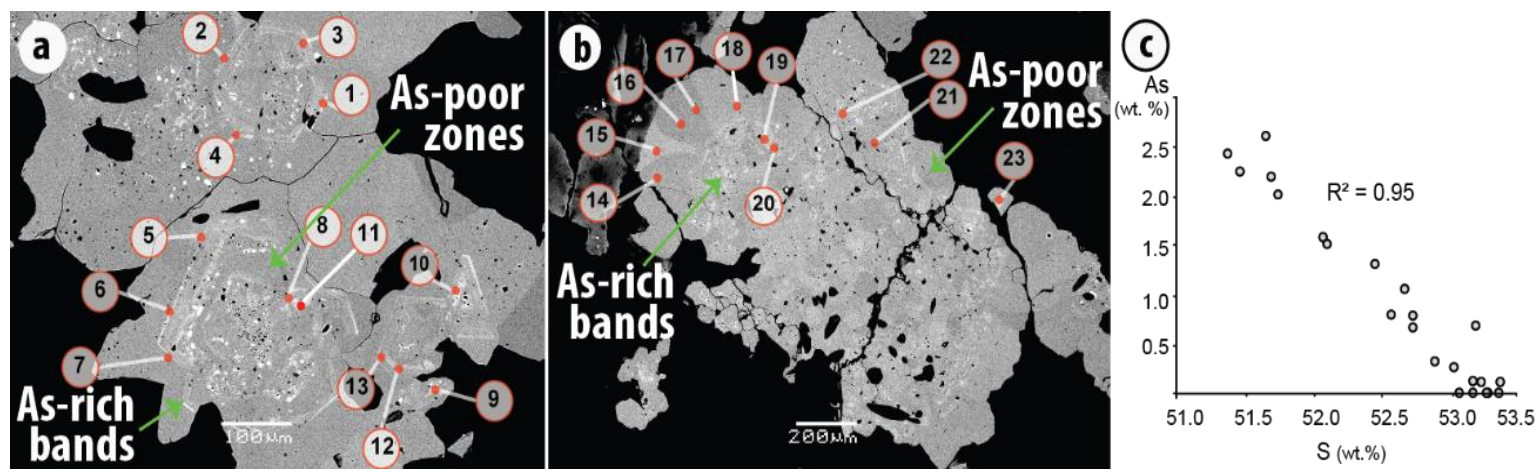

Figure 5. (a,b) SEM backscattered electron images of arsenic oscillatory-zoned PY3. Red points on the images represent electron microprobe (EMP) analytical points. (c) A plot of As (wt \%) versus S (wt \%) concentrations for arsenian PY3, showing an inverse linear correlation.

Table 1. Average values for sulfur, iron, and arsenic (in wt $\%$ ) determined on arsenian pyrites (PY3) by electron microprobe. Abbreviations: $n=$ number of selected analysis point; $\mathrm{SD}=$ standard deviation; LoD = limit of detection.

\begin{tabular}{ccccccc}
\hline $\boldsymbol{n}$ & Pyrite Zone & & S_wt $\%$ & Fe_wt $\%$ & As_wt $\%$ & Total \\
\hline \multirow{3}{*}{18} & \multirow{3}{*}{ As-rich band } & Range & $51.4-53.4$ & $45.8-46.5$ & $0.1-2.6$ & $99.5-100.1$ \\
& & Average & 52.5 & 46.2 & 1.1 & 99.8 \\
& & SD & 0.7 & 0.2 & 0.9 & 0.1 \\
\hline \multirow{2}{*}{5} & \multirow{2}{*}{ As-poor zones } & Range & $53.1-53.4$ & $46.4-46.6$ & $<$ LoD & $99.6-99.9$ \\
& & Average & 53.3 & 46.5 & $<$ LoD & 99.7 \\
& & SD & 0.1 & 0.1 & & 0.1 \\
\hline
\end{tabular}




\subsection{Invisible Cobalt, Gold, Silver, and Arsenic in Pyrite by LA-ICP-MS}

Twenty crystals of the different pyrite types were selected to be analyzed by LA-ICP-MS. The micro-chemical characterization was focused on determining the trace-element content, e.g., Co, $\mathrm{Au}, \mathrm{Ag}$, and the REEs. We also included As in the analyses because this element is a potential vector to gold-enriched zones in Porphyry-Epithermal systems [20-22,26], and because it is considered as a deleterious metal during copper ore processing [30]. The results show that the three different pyrite types can be distinguished based on the profiles of their time-resolved LA-ICP-MS spectra (Figure 6) and on their trace-element contents (Table 2). Their main characteristics are as follows:

(1) PY1 crystals (Figure 6a), which are found intergrown with chalcopyrite in all Min-Zones, are the richest in Co with concentration ranging up to 24,000 ppm, and the poorest in As with concentrations below 20 ppm; Au and Ag were systematically below the LA-ICP-MS detection limits (<LoD, Table 2). In this pyrite type, Co either occurred within the lattice or formed invisible nano-particles of Co-S sulfosalt [28], corresponding to a (Co, Ni)-rich pyrite.

(2) PY2 crystals (Figure 6b), which are found as veinlet filling, are relatively depleted in Co $(<38$ ppm) as well as As (<28 ppm) (Table 2). In this pyrite type, the spectra for Au, Ag, and Te mimic each other and their signals show a spike well above the background (Figure 6b), indicating that these elements are probably concentrated in pyrite as invisible nano-particles of Au-Ag-Te [22,24,26] instead of being within its structure. These nano-particles are recognized in the LA-ICP-MS spectra, however they are not considered in the raw data processing to obtain the element concentrations. This finding is consistent with the presence of micro-inclusions $((\mathrm{Au}, \mathrm{Ag}) \mathrm{Te})$ recognized with the SEM during ore mineral characterization (Figure 4e).

(3) PY3 crystals (Figure 6c), occurring as filling in late-stage veinlets, are the richest in As (up to $10,000 \mathrm{ppm}$ ) and $\mathrm{Au}$ (up to $4.3 \mathrm{ppm}$ ), and have relatively high cobalt contents (up to $750 \mathrm{ppm}$, Table 2). In this pyrite, the LA-ICP-MS signals for Co and As are parallel (Figure 6c). Similar to PY2, this suggests that these elements are not in the mineral's structure but probably occur in the same sulfosalt of nanometric size (invisible even under SEM observation) [30], such as cobaltite (CoAsS). PY3 can be classified as "arsenian"-type in terms of its arsenic concentration (up to wt\% levels) $[20,24,25]$.

\subsection{Minerals Hosting Rare Earth Elements}

The main REE-bearing mineral recognized in our samples is monazite-(La) $\left(\mathrm{La}(\mathrm{Ce}, \mathrm{Nd}) \mathrm{PO}_{4}\right)$ (28.95 wt\% La). In mineralized zones, monazite was found in the matrix of breccias and veinlets (Figure 7a-c), commonly associated with quartz, anhydrite, and muscovite crystals. It forms rounded grains generally smaller than $5 \mu \mathrm{m}$ (Figure $7 \mathrm{a}-\mathrm{c}$ ). Monazite was also found accompanying $\mathrm{Cu}$ sulfides, in the form of rounded grains of few microns in size $(<10 \mu \mathrm{m}$, Figure $7 \mathrm{a}-\mathrm{c})$. We focused our analyses on these latter occurrences, since $\mathrm{Cu}$ sulfides constitute part of the processed ore.

To test for the presence of REE in pyrite crystals, the ${ }^{139}$ La isotope was included in the LA-ICP-MS analytical routine. Lanthanum was always below detection, except for one case where its time-resolved spectrum showed a very high peak (Figure 7d), greater than that of most trace elements. This suggests that the laser ablated a deeply-seated crystal of monazite that was not visible on the surface of the sample. This confirms that lanthanum (and probably other REE) only occurs as micron (or nanometric) size minerals in pyrite, rather than as a trace metal in the lattice. Based on this and similar analyses, the contents of lanthanum (La) were estimated for two pyrite crystals following the method described in Reference [16] and taking NIST SRM 610 [17] as external calibrator. This resulted in concentrations of the order of 4000 ppm La. 

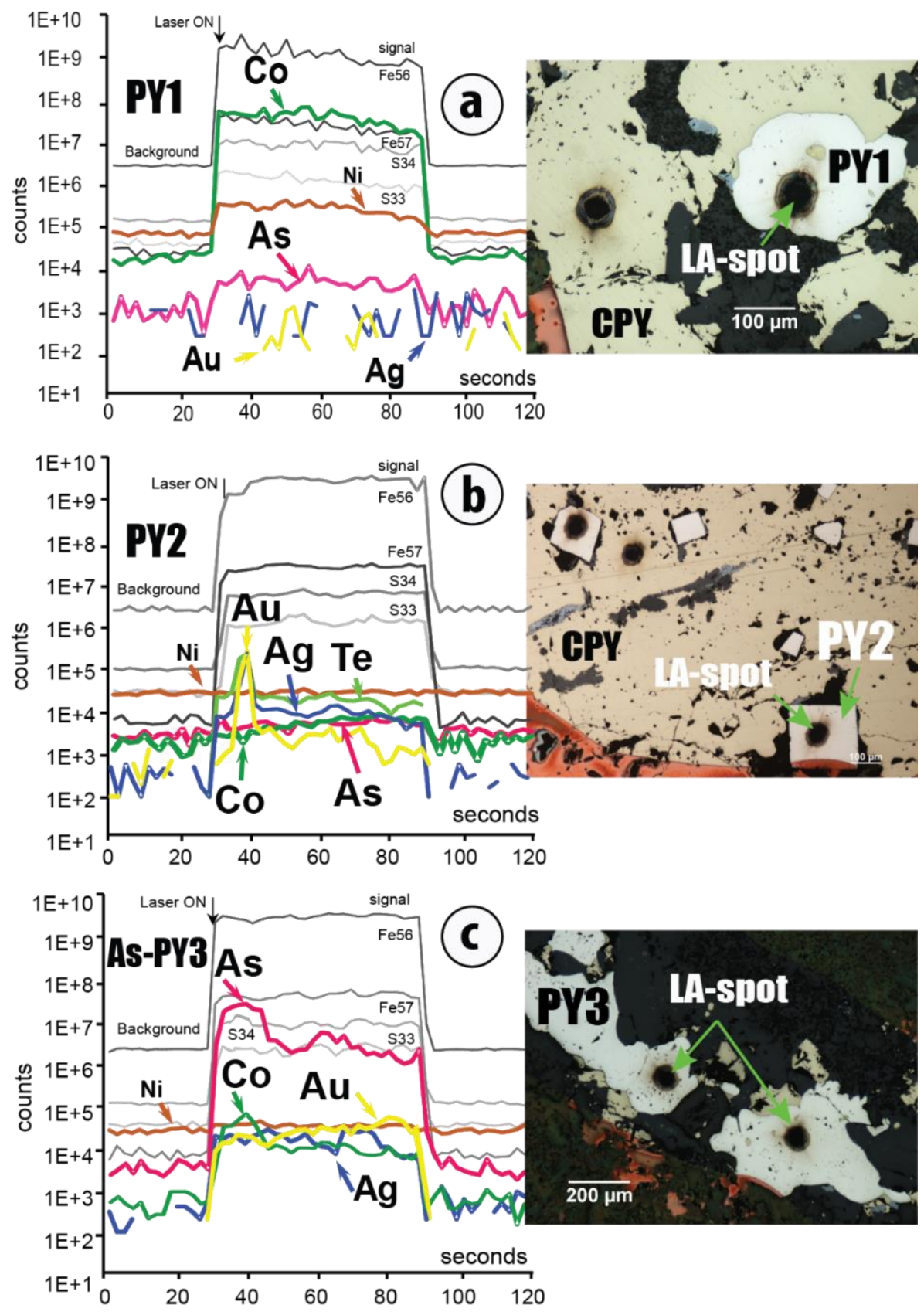

Figure 6. (a-c) Typical LA-ICP-MS patterns (in counts per second) of selected trace-element signals for the three pyrite types. Locations of laser-ablation spots (LA-spot) are shown in the reflected-light microphotographs on the right, which were taken after laser ablation analysis. 

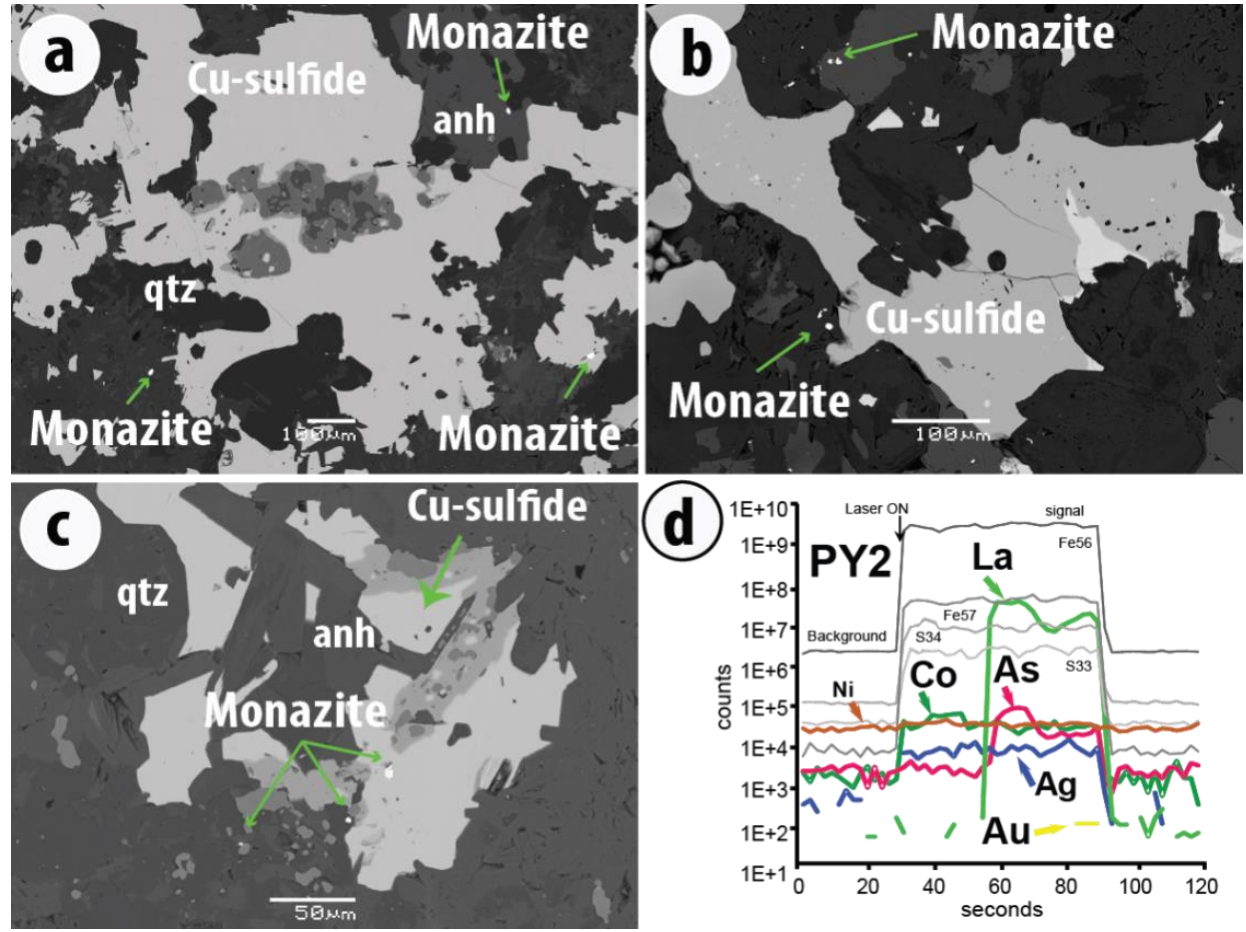

Figure 7. (a-c) SEM backscattered electron images of ore material showing monazite grains found in the breccia and veins matrix, as well as other mineral micro-inclusions in sulfide crystals. anh = anhydrite; $\mathrm{ms}=$ muscovite; qtz = quartz. (d) LA-ICP-MS pattern (in cps) for pyrite containing a nanometric inclusion, possibly monazite, not visible under SEM.

Table 2. Cobalt, nickel, arsenic, silver, and gold concentrations (in ppm) determined in pyrite by LA-ICP-MS. All three pyrite types (PY1-3) were analyzed. LoD: limit of detection.

\begin{tabular}{cccccc}
\hline Pyrite Type & Co $(\mathbf{p p m})$ & Ni $(\mathbf{p p m})$ & As $(\mathbf{p p m})$ & Ag $(\mathbf{p p m})$ & Au (ppm) \\
\hline LoD & 0.2 & 0.6 & 0.8 & 0.05 & 0.02 \\
PY1 & $24,051 \pm 3400$ & $580 \pm 47$ & $15 \pm 2$ & $<\mathrm{LoD}$ & $<\mathrm{LoD}$ \\
PY1 & $173 \pm 22$ & $420 \pm 43$ & $2 \pm 0.8$ & $<\mathrm{LoD}$ & $<\mathrm{LoD}$ \\
PY1 & $320 \pm 41$ & $315 \pm 31$ & $14 \pm 2$ & $<\mathrm{LoD}$ & $<\mathrm{LoD}$ \\
PY1 & $4380 \pm 584$ & $280 \pm 29$ & $5 \pm 0.8$ & $<\mathrm{LoD}$ & $<\mathrm{LoD}$ \\
PY1 & $8560 \pm 950$ & $120 \pm 21$ & $12 \pm 2$ & $<\mathrm{LoD}$ & $<\mathrm{LoD}$ \\
PY1 & $12,180 \pm 980$ & $778 \pm 65$ & $20 \pm 2$ & $<\mathrm{LoD}$ & $<\mathrm{LoD}$ \\
PY2 & $38 \pm 5$ & $1 \pm 0.2$ & $9 \pm 0.8$ & $0.1 \pm 0.05$ & $<\mathrm{LoD}$ \\
PY2 & $8 \pm 1$ & $2 \pm 0.3$ & $28 \pm 3$ & $0.9 \pm 0.05$ & $<\mathrm{LoD}$ \\
PY2 & $1 \pm 0.3$ & $3 \pm 0.3$ & $2 \pm 0.8$ & $1.8 \pm 0.08$ & $0.05 \pm 0.02$ \\
PY2 & $2 \pm 0.7$ & $3 \pm 0.3$ & $3 \pm 0.9$ & $1.9 \pm 0.08$ & $0.05 \pm 0.02$ \\
PY2 & $4 \pm 0.5$ & $11 \pm 2$ & $4 \pm 0.9$ & $2.1 \pm 0.09$ & $0.08 \pm 0.02$ \\
PY2 & $1 \pm 0.3$ & $10 \pm 1$ & $6 \pm 1$ & $0.4 \pm 0.05$ & $<\mathrm{LoD}$ \\
As-poor -PY3 & $496 \pm 33$ & $63 \pm 7$ & $1 \pm 0.8$ & $<\mathrm{LoD}$ & $<\mathrm{LdD}$ \\
As-rich-PY3 & $444 \pm 38$ & $69 \pm 5$ & $1181 \pm 137$ & $2.2 \pm 0.08$ & $0.3 \pm 0.05$ \\
As-rich-PY3 & $151 \pm 23$ & $40 \pm 4$ & $2288 \pm 298$ & $2.1 \pm 0.08$ & $0.4 \pm 0.05$ \\
As-rich-PY3 & $27 \pm 3$ & $<\mathrm{LdD}$ & $2526 \pm 331$ & $1.0 \pm 0.08$ & $0.3 \pm 0.05$ \\
As-rich-PY3 & $463 \pm 39$ & $72 \pm 6$ & $2645 \pm 351$ & $2.1 \pm 0.09$ & $0.4 \pm 0.04$ \\
As-rich-PY3 & $355 \pm 31$ & $31 \pm 3$ & $2766 \pm 388$ & $0.8 \pm 0.05$ & $0.5 \pm 0.04$ \\
As-rich-PY3 & $679 \pm 58$ & $50 \pm 5$ & $4585 \pm 533$ & $2.3 \pm 0.09$ & $0.9 \pm 0.06$ \\
As-rich-PY3 & $512 \pm 51$ & $68 \pm 5$ & $4156 \pm 520$ & $4.0 \pm 0.1$ & $0.8 \pm 0.06$ \\
As-rich-PY3 & $219 \pm 33$ & $137 \pm 24$ & $3290 \pm 412$ & $3.9 \pm 0.1$ & $0.6 \pm 0.05$ \\
As-rich-PY3 & $142 \pm 15$ & $19 \pm 2$ & $4004 \pm 513$ & $0.2 \pm 0.05$ & $0.7 \pm 0.12$ \\
As-rich-PY3 & $10 \pm 1$ & $8 \pm 1$ & $10,891 \pm 998$ & $3.1 \pm 0.08$ & $4.3 \pm 0.65$ \\
As-rich-PY3 & $747 \pm 61$ & $46 \pm 5$ & $6090 \pm 699$ & $2.9 \pm 0.08$ & $2.1 \pm 0.35$ \\
\hline
\end{tabular}




\section{Discussion: Is Metal-Selective Mining the Key for Critical-Metal Supply?}

The need for critical metals during the next decades pushes the economic geologist toward exploring non-common sources for these resources. However, they can also be found in most mineral deposits at trace-element concentrations. In the case of a porphyry copper deposits, here we show how a high-resolution mineral characterization can efficiently determine critical metals and their host minerals; it also allows to track the final destination of a specific metal (whether economic or detrimental, e.g., As) in the current metallurgical ore processing workflow, e.g., Cu-sulfide flotation concentrate or tailings for our case study (Figure 1b). Extended to other deposit types, our approach can reveal to be a strategic tool in developing high-impact multi-metal business (Figure 1b).

\subsection{Cobalt Host-Minerals and Final Metal Destination}

Pyrite is the main cobalt host in the deposit studied, which is a common feature in most porphyry-type deposits. However, we have shown the existence of different types of pyrite, not all of which concentrate Co; indeed, PY1 is the only Co-rich pyrite type at Los Sulfatos, with grades up to 24,000 ppm Co. Such grades could forecast a potential business scenario with Co as a by-product. More interestingly, PY1 crystals, which have low As concentrations (Figure 6c), are found systematically associated with chalcopyrite in the copper Min-Zones, implying that these crystals belong to the mine material considered as the target for copper ore processing. This means that Co-rich pyrites (PY1) will follow the entire metallurgical ore processing until the final separation of the mined material into $\mathrm{Cu}$-sulfide flotation concentrate and "waste" material. Using the present day approach, this would lead to two possible situations: If pyrite liberation is well-controlled in the metallurgical processing, the final destination for $\mathrm{Co}$ is the tailings (Figure 1b); failing that, the anomalous Co concentrations detected in the $\mathrm{Cu}$-flotation concentrates (Figure $1 \mathrm{~b}$ ) would likely lead to, mistakenly, envisage the presence of Co in the $\mathrm{Cu}$ sulfides, rather than recognize $\mathrm{Co}$-rich pyrite misplacement during the ore processing.

\subsection{Lanthanum Host-Minerals and Final Metal Destination}

The main lanthanum ore mineral found in our samples is monazite $(\mathrm{La})$, which was recognized both as free visible grains in the matrix of hydrothermal breccia as well as invisible nano-inclusions (up to $4000 \mathrm{ppm} \mathrm{La)} \mathrm{hosted} \mathrm{in} \mathrm{pyrite} \mathrm{crystals.} \mathrm{In} \mathrm{both} \mathrm{cases,} \mathrm{La-Monazite} \mathrm{grains} \mathrm{will} \mathrm{be} \mathrm{concentrated} \mathrm{in}$ the tailings as a part of "waste" material (Figure 1b). Monazite crystals were also recognized in copper sulfides (chalcopyrite and bornite), where they were incorporated as micro- and/or nano-inclusions. In this case, La-bearing particles would be contained in the flotation concentrates (Figure 1b), producing an increase of equivalent $\mathrm{Cu}$-grades by considering lanthanum content as by-product.

\subsection{Gold $(+A g$ and $\mathrm{Te})$ Host-Minerals and Final Metal Destination}

In addition to Co, pyrite is also a key host of $\mathrm{Au}$ at Los Sulfatos. However, while Co is found only in PY1, gold forms (1) inclusions of sulfosalts as visible micro-grains and invisible nano-particles in pyrite PY2, systematically accompanied by Ag and Te, and (2) Au accompanied by As in the lattice of arsenian PY3.

Because pyrite PY2 is associated with chalcopyrite in the copper Min-zones, during the metallurgical process a lot of this pyrite will end up to the tailing, enriching it in Au as well as in Ag and Te (Figure 1b), two critical metals for the development of green technologies. Similarly, although visible gold grains were not detected in PY3, textural and micro-chemical characteristics of this As-rich pyrite type indicate a high possibility of finding visible gold, as is the case in other porphyry copper deposits [22,26] and predicted by our Au-As analysis (Figures 5 and 8). Therefore, although the economic potential of arsenian PY3 in the late-stage veinlets was not recognized at Los Sulfatos, we strongly suggest that these zones be targeted for gold exploration. 


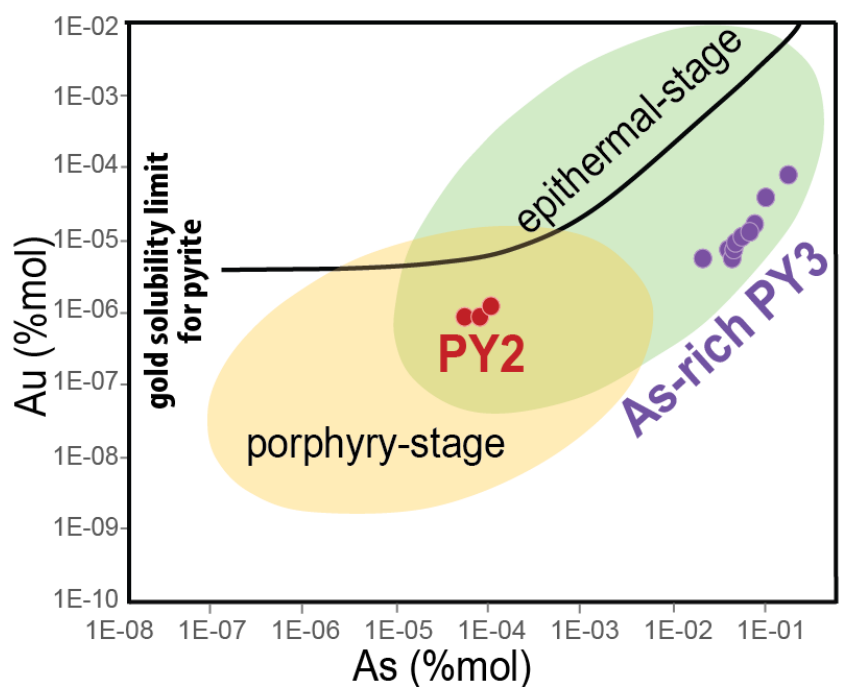

Figure 8. Plot of Au vs. As for the gold-bearing pyrite types in the "Los Sulfatos" deposit. Concentrations are obtained by LA-ICP-MS and are plotted on a logarithmic scale. The solubility limit for gold in pyrites is from Reference [31] and the fields for porphyry and epithermal pyrite deposits worldwide are from Reference [25].

\subsection{Arsenian Pyrite as a Proxy for Gold Exploration in Porphyry Copper Deposits}

Although Au concentrations measured in arsenian pyrite (PY3) are too low ( $<4.3 \mathrm{~g} / \mathrm{t}$ of Au in pyrite) for it to be considered economic (unless it is a by-product), in recent years it has been shown that the textural features and metal contents of arsenian pyrite can provide a vector to gold-enriched zones, particularly in porphyry-epithermal systems where telescoping of mineralized zones are developed [20-22,26]. To apply this tool, it is necessary to identify arsenian pyrite and to classify the different types/generations of pyrite according to their metallogenic framework [20-22,24,26]. Accordingly, Figure 8 shows a plot of As vs. Au contents for pyrite types 2 and 3 at Los Sulfatos (Table 2), along with the solubility limit of gold in pyrite (from Reference [31]) and the fields for porphyry-stage and epithermal-stage pyrites proposed by Reference [25]. All our data plot below the Au-saturation limit, indicating that invisible gold is mainly included in the crystal lattice of pyrite, and/or in form of invisible nano-particles of metallic gold. It is possible, however, that at least some invisible gold occurs as sulfosalts of $\mathrm{Au}-\mathrm{Ag}$-Te, such as sylvanite $(\mathrm{Ag}, \mathrm{Au}) \mathrm{Te}_{2}$, thus having a different solubility than that of the native metal.

The differences in As concentration between early-formed pyrite (PY1 and PY2) and late-formed arsenian pyrite (PY3) are coherent with the geochemical behavior of porphyry-epithermal systems [20-22,26], in which As is geochemically decoupled from $\mathrm{Cu}$. This occurs during fluid-phase separation (or boiling) that commonly takes place in these systems, forming a low-density As-rich vapor and a denser $\mathrm{Cu}$-rich brine [25]. This copper-arsenic selective geochemical partitioning is responsible for generating a separation into $\mathrm{Cu}$-bearing sulfides, preferentially precipitating during early porphyry mineralizing stages, and As-bearing sulfides that preferentially concentrate in late-stage fracture networks [20-22,26]. Our results are thus consistent with a porphyry-stage signature for PY1 and PY2, while arsenian PY3 is more likely of epithermal affiliation.

The identification of gold-bearing pyrite, i.e., arsenian PY3, characterized by an epithermal trace-element signature (Figure 8), is an important result because it indicates the probable presence of a gold-enriched zone, likely superimposed onto the known deposit. Although visible gold occurs commonly in enriched arsenian-pyrite zones [22,26], such gold-enriched zones are not systematically characterized in porphyry deposits, mainly because gold is not contained in Cu-sulfides (e.g., chalcopyrite, bornite). It thus appears evident that detailed characterization of metallic minerals such as pyrite [26] should be a standard practice in mining protocols. 


\subsection{High-Resolution Mineral Characterization as a Tool for Metal-Zones Definition}

In this study, we have shown that porphyry copper deposits can contain trace concentrations of critical metals, and that these metals are not included in current mining models. We have also seen that a specific mineral such as pyrite can host several critical metals, although we have also shown that different generations contain different metals. This implies that the current definition of a single Pyrite-Zone in a deposit characterization is not a suitable approach to explore economic metal-enriched zones. To address this issue, we propose an evolution of the Min-Zone definition, the Metal-Zone concept, in which the metal-bearing minerals are characterized from a metallogenic approach, thereby defining its economic-metal signature (e.g., Co-rich-PY), instead of a simple mineral paragenetic signature. With this information, it will be possible to define Metal-Zones (i.e., enriched zones) for each metal of interest, and to delineate them according to the host mineral generation. At Los Sulfatos these would be a Co-rich-PY1 zone, an Au-Ag-Te-rich-PY2 zone, and an Au-rich-PY3 zone.

With this approach, selective-metal mining can be designed both in active mining operations and in prospects. In the first case, the economic viability to exploit and to process pyrite metal content will be amortized by the installed investment related to copper mining, with tailings representing the main target for most current mine operations. In the second case, this information can be used to design more sophisticated metallurgical solutions that include these metals as by-products in a multi-metal economic modeling. Our study offers a new perspective to explore the economic potential for critical metal exploitation in porphyry copper deposits, highlighting the role of innovation in mineral characterization towards the development of a circular economy in mining.

\subsection{Implication for Metallurgical Processing of Critical Metals}

We have shown that pyrite is a prime host for critical metals, and thus the target to look for in waste material mining. This means that a tailing enriched in pyrite is an easy prospect to explore for critical metals. However, only high-resolution mineral characterization can allow determination of its specific metal content, whether it is concentration (metal grade) or the manner of occurrence for each metal (e.g., visible, invisible, in the structure, etc.).

Processing models for $\mathrm{Co}, \mathrm{Au}$, and $\mathrm{Ag}$ extraction from pyrites have been previously proposed in the literature [32-34], and vary from traditional high-temperature (up to $1500^{\circ} \mathrm{C}$ ) roasting of pyrite, including chloridizing and sulfating roasting processes [32], to more recently proposed treatment in a high-temperature water vapor medium [33]. For the roasting case [32] the $\mathrm{Co}$ and $\mathrm{Au}$ leach recoveries are higher by chloridizing roasting $(86.5 \%$ for $\mathrm{Co}$ and $90 \%$ for $\mathrm{Au})$ than sulfating roasting $(80 \%$ for $\mathrm{Co}$ and $83.6 \%$ for $\mathrm{Au}$ ). However, both roasting processes have some disadvantages, including sulfur dioxide $\left(\mathrm{SO}_{2}\right)$ gas production and the final recuperation of iron as hematite, which is a non-stable chemical compound. Nowadays new pyrite processing technologies [33] are starting to offer the possibility to generate metal recoveries that are environmentally safe, in which the generated waste material is pure sponge iron, instead of hematite, and preventing $\mathrm{SO}_{2}$ to be released into the atmosphere. Even if this technology is still developing, it shows a pathway to progress in critical metal processing from pyrite, improving both the economic and environmental efficiency in a mining operation.

Finally, we propose that the combination between a high-resolution mineral characterization and environmentally friendly metallurgical processing for pyrite is the key to obtain new sources of critical metals supply by applying the circular economy concept in pyrite-rich tailings. This is a serious opportunity to evolve to a more realistic green mining business, generating a good synchronicity between the economic benefits and the tailings remediation in the mining value chain.

\section{Concluding Remarks}

In the Los Sulfatos porphyry copper deposit, pyrite is the main host mineral for a number of critical metals, i.e., $\mathrm{Co}$, $\mathrm{La}$, and $\mathrm{Au}$, as well as $\mathrm{Ag}$, $\mathrm{Te}$, and As. These metals occur as mineral inclusions, both as visible grains and invisible nano-particles. Different generations of pyrite host specific metals. 
Cobalt is contained in the earliest pyrite that forms in the deposit, PY1; Au, accompanied by Ag and Te, is found in PY2 whereas PY3 contains Au and As. PY1 and PY2 correspond to porphyry-style pyrite while PY3 has a quasi-epithermal signature. Rare earth elements occur in the form of monazite-(La), which was found as invisible nano-inclusions in PY2 crystals and as micron-size grains in the matrix of the hydrothermal breccia.

Concentrations of invisible metals were calculated by micro-chemical characterization. Results indicate up to 24,000 ppm Co for PY1 and PY2, estimated concentrations of some $4000 \mathrm{ppm}$ La in PY2, and possible grades of $4.3 \mathrm{ppm} g / \mathrm{t}$ Au contained in PY3. These proportions add to the visible amounts of $\mathrm{Au}, \mathrm{Ag}$, and $\mathrm{Te}$, all economic metals that are mainly stocked in the tailings. It follows that tailings, especially those with high contents of pyrite, can represent top prospects for exploring critical metal potential in porphyry-type mining operations. However, evaluation of critical metal occurrences must be carried out by applying high-resolution mineral characterization, which represents an essential tool to develop selective-metal mining. Detailed metal tracking must be focalized on both economic metals as well as on deleterious elements, which is a piece of crucial information to determine the final destination of each critical metal, i.e., tailings or sulfide flotation concentrates.

In addition to tailings, another exciting source of supply for critical metals can be the Cu-flotation concentrates, in the case where these metals occur as traces in the $\mathrm{Cu}$-ore sulfides (e.g., chalcopyrite and bornite). In this case, the systematic implementation of the high-resolution mineral characterization directly on flotation concentrate samples will provide the possibility to incorporate the critical metal content into the economic value of the concentrates, resketching the market of this commodity.

Author Contributions: Conceptualization, G.V., D.C., S.S. and I.V.; methodology, G.V., S.S. and A.P.; validation, S.S., I.V. and M.P.; resources, I.V., S.S., and M.P.; writing-original draft preparation, G.V., S.S., and D.C.; writing-review and editing, S.S., G.V.; visualization, G.V. and D.C.; supervision, I.V.; project administration, I.V. and M.P. All authors have read and agreed to the published version of the manuscript.

Funding: This research received no external funding.

Acknowledgments: We are grateful to S. Gouy and Ph. de Parseval for their help during SEM and EMP analyses at the Centre de Micro-Caractérisation Raimond Castaing (UMS 3623) in Toulouse, France, and T. Aigouy during the SEM analyses at the GET Laboratory in Toulouse. We would also like to thank J. Chmeleff and C. Duquenoy for their technical assistance on the LA-ICP-MS analyses at the GET Laboratory in Toulouse, France. Constructive comments by two anonymous reviewers substantially improved the quality of this manuscript.

Conflicts of Interest: The authors declare no conflict of interest.

\section{References}

1. Grandell, L.; Lehtilä, A.; Kivinen, M.; Koljonen, T.; Kihlman, S.; Lauri, L.S. Role of critical metals in the future markets of clean energy technologies. Renew. Energy 2016, 95, 53-62. [CrossRef]

2. Bensalah, N.; Dawood, H. Review on Synthesis, Characterizations, and Electrochemical Properties of Cathode Materials for Lithium Ion Batteries. J. Mater. Sci. Eng. 2016, 5. [CrossRef]

3. Ghatak, K.; Basu, S.; Das, T.; Sharma, V.; Kumar, H.; Datta, D. Effect of cobalt content on the electrochemical properties and structural stability of NCA type cathode materials. Phys. Chem. Chem. Phys. 2018, 20, 22805-22817. [CrossRef] [PubMed]

4. Jin, Y.; Kim, J.; Guillaume, B. Review of critical material studies. Resour. Conserv. Recycl. 2016, 113, 77-87. [CrossRef]

5. Leader, A.; Gaustad, G.; Babbitt, C. The effect of critical material prices on the competitiveness of clean energy technologies. Mater. Renew. Sustain. Energy 2019, 8, 8. [CrossRef]

6. Pašava, J.; Vymazalová, A.; Košler, J.; Koneev, R.I.; Jukov, A.V.; Khalmatov, R.A. Platinum-group elements in ores from the Kalmakyr porphyry $\mathrm{Cu}-\mathrm{Au}-\mathrm{Mo}$ deposit, Uzbekistan: Bulk geochemical and laser ablation ICP-MS data. Miner. Depos. 2010, 45, 411-418. [CrossRef]

7. Zarasvandi, A.; Rezaei, M.; Raith, J.G.; Pourkaseb, H.; Asadi, S.; Saed, M.; Lentz, D.R. Metal endowment reflected in chemical composition of silicates and sulfides of mineralized porphyry copper systems, Urumieh-Dokhtar magmatic arc, Iran. Geochim. Cosmochim. Acta 2018, 223, 36-59. [CrossRef] 
8. Crespo, J.; Reich, M.; Barra, F.; Verdugo, J.J.; Martínez, C. Critical Metal Particles in Copper Sulfides from the Supergiant Río Blanco Porphyry Cu-Mo Deposit, Chile. Minerals 2018, 8, 519. [CrossRef]

9. Irarrazaval, V.; Sillitoe, R.H.; Wilson, A.J.; Toro, J.C.; Robles, W.; Lyall, G.D. Discovery History of a Giant, High-Grade, Hypogene Porphyry Copper-Molybdenum Deposit at Los Sulfatos, Los Bronces-Río Blanco District, Central Chile. In The Challenge of Finding New Mineral ResourcesGlobal Metallogeny, Innovative Exploration, and New Discoveries; Society of Economic Geologists: Littleton, CO, USA, 2010; pp. 253-269.

10. Toro, J.C.; Ortúzar, J.; Zamorano, J.; Cuadra, P.; Hermosilla, J.; Spröhnle, C. Protracted magmatic-hydrothermal history of the Río Blanco-Los Bronces district, Central Chile: Development of world's greatest known concentration of copper. In Geology and Genesis of Major Copper Deposits and Districts of the World: A Tribute to Richard H. Sillitoe; Hedenquist, J.W., Harris, M., Camus, F., Eds.; Society of Economic Geologists: Littleton, CO, USA, 2012; pp. 105-126.

11. Deckart, K.; Silva, W.; Spröhnle, C.; Vela, I. Timing and duration of hydrothermal activity at the Los Bronces porphyry cluster: An update. Miner. Depos. 2014, 49, 535-546. [CrossRef]

12. Riesner, M.; Simoes, M.; Carrizo, D.; Lacassin, R. Early exhumation of the Frontal Cordillera (Southern Central Andes) and implications for Andean mountain-building at $33.5^{\circ}$ S. Sci. Rep. 2019, 9. [CrossRef]

13. Carrizo, D.; Barros, C.; Velasquez, G. The Arsenic Fault-Pathfinder: A Complementary Tool to Improve Structural Models in Mining. Minerals 2018, 8, 364. [CrossRef]

14. Van Achterbergh, E.; Ryan, C.G.; Griffin, W.L. Data Reduction Software for LA-ICP-MS; Mineralogical Association of Canada Short Course Notes: Calgary, AB, Canada, 2001; Volume 29, pp. 239-243.

15. Sylvester, P.J.; Cabri, L.J.; Tubrett, M.N.; McMahon, G.; Laflamme, J.H.G.; Peregoedova, A. Synthesis and evaluation of a fused pyrrhotite standard reference material for platinum group element and gold analysis by laser ablation-ICP-MS. In Proceedings of the 10th International Platinum Symposium, Oulu, Finland, 8-11 August 2005; pp. 16-20.

16. Velásquez, G.; Salvi, S.; Béziat, D.; Borisova, A.Y. In Situ Determination of Au and Cu in Natural Pyrite by Near? Infrared Femtosecond Laser Ablation? Inductively Coupled Plasma? Quadrupole Mass Spectrometry: No Evidence for Matrix Effects. Geostand. Geoanal. Res. 2012, 36, 315-324. [CrossRef]

17. Pearce, N.J.; Perkins, W.T.; Westgate, J.A.; Gorton, M.P.; Jackson, S.E.; Neal, C.R.; Chenery, S.P. A compilation of new and published major and trace element data for NIST SRM 610 and NIST SRM 612 glass reference materials. Geostand. Geoanal. Res. 1997, 21, 115-144. [CrossRef]

18. Borisova, A.; Thomas, R.; Salvi, S.; Candaudap, F.; Lanzanova, A.; Chmeleff, J. Tin and associated metal and metalloid geochemistry by femtosecond LA-ICP-QMS microanalysis of pegmatite-leucogranite melt and fluid inclusions: New evidence for melt-melt-fluid immiscibility. Mineral. Mag. 2012, 76, 91-113. [CrossRef]

19. Sillitoe, R.H. Characteristics and controls of the largest porphyry copper-gold and epithermal gold deposits in the circum-Pacific region. Aust. J. Earth Sci. 1997, 44, 373-388. [CrossRef]

20. Reich, M.; Deditius, A.; Chryssoulis, S.; Li, J.-W.; Ma, C.-Q.; Parada, M.Á.; Barra, F.; Mittermayr, F. Pyrite as a record of hydrothermal fluid evolution in a porphyry copper system: A SIMS/EMPA trace element study. Geochim. Cosmochim. Acta 2013, 104, 42-62. [CrossRef]

21. Franchini, M.; McFarlane, C.; Maydagan, L.; Reich, M.; Lentz, D.R.; Meinert, L.; Bouhier, V. Trace metals in pyrite and marcasite from the Agua Rica porphyry-high sulfidation epithermal deposit, Catamarca, Argentina: Textural features and metal zoning at the porphyry to epithermal transition. Ore Geol. Rev. 2015, 66, 366-387. [CrossRef]

22. Sykora, S.; Cooke, D.R.; Meffre, S.; Stephanov, A.S.; Gardner, K.; Scott, R.; Selley, D.; Harris, A.C. Evolution of pyrite trace element compositions from porphyry-style and epithermal conditions at the Lihir gold deposit: Implications for ore genesis and mineral processing. Econ. Geol. 2018, 113, 193-208. [CrossRef]

23. Mu, Y.; Peng, Y.; Lauten, R.A. The depression of pyrite in selective flotation by different reagent systems-A Literature review. Miner. Eng. 2016, 96, 143-156. [CrossRef]

24. Velásquez, G.; Béziat, D.; Salvi, S.; Siebenaller, L.; Borisova, A.Y.; Pokrovski, G.S.; De Parseval, P. Formation and deformation of pyrite and implications for gold mineralization in the El Callao District, Venezuela. Econ. Geol. 2014, 109, 457-486. [CrossRef]

25. Deditius, A.P.; Reich, M.; Kesler, S.E.; Utsunomiya, S.; Chryssoulis, S.L.; Walshe, J.; Ewing, R.C. The coupled geochemistry of $\mathrm{Au}$ and $\mathrm{As}$ in pyrite from hydrothermal ore deposits. Geochim. Cosmochim. Acta 2014, 140, 644-670. [CrossRef] 
26. Le Mignot, E.; Siebenaller, L.; Béziat, D.; André-Mayer, A.-S.; Reisberg, L.; Salvi, S.; Velasquez, G.; Zimmermann, C.; Naré, A.; Franceschi, G. The paleoproterozoic copper-gold deposits of the Gaoua district, Burkina Faso: Superposition of orogenic gold on a porphyry copper occurrence? Econ. Geol. 2017, 112, 99-122. [CrossRef]

27. Fleet, M.E.; Mumin, A.H. Gold-bearing arsenian pyrite and marcasite from Carlin Trend deposits and laboratory synthesis. Am. Mineral. 1997, 82, 182-193. [CrossRef]

28. Deditius, A.P.; Utsunomiya, S.; Reich, M.; Kesler, S.E.; Ewing, R.C.; Hough, R.; Walshe, J. Trace metal nanoparticles in pyrite. Ore Geol. Rev. 2011, 42, 32-46. [CrossRef]

29. Cook, N.J.; Ciobanu, C.L.; Danyushevsky, L.V.; Gilbert, S. Minor and trace elements in bornite and associated $\mathrm{Cu}-(\mathrm{Fe})$-sulfides: A LA-ICP-MS studyBornite mineral chemistry. Geochim. Cosmochim. Acta 2011, 75, 6473-6496. [CrossRef]

30. Schmandt, D.S.; Cook, N.J.; Ehrig, K.; Gilbert, S.; Wade, B.P.; Rollog, M.; Ciobanu, C.L.; Kamenetsky, V.S. Uptake of trace elements by baryte during copper ore processing: A case study from Olympic Dam, South Australia. Miner. Eng. 2019, 135, 83-94. [CrossRef]

31. Reich, M.; Kesler, S.E.; Utsunomiya, S.; Palenik, C.S.; Chryssoulis, S.L.; Ewing, R.C. Solubility of gold in arsenian pyrite. Geochim. Cosmochim. Acta 2005, 69, 2781-2796. [CrossRef]

32. Okgör, O.; Topkaya, Y. Extraction of cobalt and copper from Küre pyrite concentrate. Miner. Eng. 1988, 1, 213-223. [CrossRef]

33. Hakobyan, K.; Melkomyan, A.; Karamyan, G. New Technology of Processing Pyrite Concentrate. IFAC Proc. Vol. 2013, 46, 321-324. [CrossRef]

34. Sole, K.C.; Parker, J.; Cole, P.M.; Mooiman, M.B. Flowsheet options for cobalt recovery in African copper-cobalt hydrometallurgy circuits. Miner. Proc. Extr. Metall. Rev. 2019, 40, 194-206. [CrossRef]

(C) 2020 by the authors. Licensee MDPI, Basel, Switzerland. This article is an open access article distributed under the terms and conditions of the Creative Commons Attribution (CC BY) license (http://creativecommons.org/licenses/by/4.0/). 